\title{
MICRONUCLEI AND G2 ASSAYS FOR ASSESSMENT OF CHROMOSOMAL RADIOSENSITIVITY AS ASSISTANT TOOL IN RADIOTHERAPY: METHOD-COMPARISON STUDY
}

\author{
Kamilè Guogytė ${ }^{1}$, Aista Plieskienè ${ }^{2}$, Olga Sevriukova ${ }^{1}$, Rima Ladygiené ${ }^{1}$, \\ Julius Žiliukas', Vinsas Janušonis² \\ ${ }^{1}$ Radiation Protection Centre, Vilnius, Lithuania, ${ }^{2}$ Klaipeda University Faculty of Health Sciences, \\ Klaipeda University Hospital, Lithuania
}

Key words: individual radiosensitivity, G2 radiosensitivity assay, cytokinesis-block micronucleus assay, radiotherapy.

\begin{abstract}
Summary
Radiation therapy is widely used for cancer treatment. Medical application of ionizing radiation can cause different responses in human depending on individual radiosensitivity. Therefore, assessment of individual radiosensitivity could be proposed as assistant tool in optimizing radiotherapy. The cytokinesis-block micronucleus and G2 chromosomal radiosensitivity assays were proposed as appropriate methods for assessment of individual radiosensitivity. In current study we carried out a pilot cytokinesis-block micronucleus and G2 chromosomal radiosensitivity assays comparison by evaluating specificity of chromatid breaks yield and micronuclei frequency in peripheral blood lymphocytes as biomarkers of individual radiosensitivity in three cancer patients treated with radiotherapy. Our study revealed positive correlation between higher increase in frequency of micronuclei and chromatid breaks after in vitro irradiation in radiotherapy patients peripheral blood lymphocytes with occurrence of adverse radiation effects in tissue which are not being targeted. G2 assay appeared to be more sensitive than micronuclei assay for assessment of irradiation-induced alterations in individual radiosensitivity during the radiotherapy that could affect development of treatment side effects. Therefore, further investigations involving more radiotherapy patients as well as healthy donors are required to select the most sensitive method and reveal the pos-
\end{abstract}

sible correlation between individual radiosensitivity and adverse effect of radiotherapy.

\section{Introduction}

Radiotherapy is one of the most commonly used methods for cancer treatment. Beside therapeutic effects, it can cause adverse reactions to radiation treatment in no-target normal tissues that can also raise risk in development of secondary cancer $[1,2]$. Nowadays medical and scientific communities make significant efforts in searching for the most efficient ways to optimize medical exposure, reduce incidence and severity of radiotherapy side effects. Since it was found that human can experience different reactions to the same dose of ionizing radiation, individual radiosensitivity was proposed to be an important factor for development of radiotherapy related side effects $[3,4]$. Therefore, the appropriate method for estimation of individual radiosensitivity could be used as assistant tool in radiotherapy: identified radiosensitive cancer patients could be excluded from dose intensification, and more resistant one might profit from dose escalation [5].

Radiation-induced cytogenetic effects and efficiency of DNA damage reparation mechanisms supposed to be fateful for patients susceptibility to radiation treatment side effects $[6,7]$. Induction of chromosomal aberration has been proposed as possible marker of increased individual radiosensitivity as well as that may have increased chances of developing a cancer [8]. Increased radiosensitivity was found in Ataxia-telangiectasia (AT), Down's syndrome, Li-Fraumeni syndrome, Wilm's tumor and systemic lupus erythematosus $[9,10]$ patients that are classified as cancer prone syndromes.

The cytokinesis-block micronucleus and G2 chromosomal radiosensitivity assays were proposed as most suitable 
cytogenetic methods to evaluate individual radiosensitivity in vitro.

According to Pantelias et al. increased number of chromatid breaks radiation-induced during G2 stage of cell cycle could be assumed as sensitive biomarker for radiosensitivity. The important difference of authors proposed protocol with conventional G2 assay is application of caffeine-induced G2-M checkpoint arrest to simulate high radiosensitivity level specific for AT syndrome patients. Individual radiosensitivity is assessed by comparing cells ability to repair radiation induced DNA damage to AT - like lowest reparation efficiency (number of chromatid breaks when G2 checkpoint is abrogated with caffeine) [11]. The possibility to apply the G2 assay in peripheral blood lymphocytes for investigation of association between chromosomal radiosensitivity and genetic predisposition to cancer was also revealed [12].

The other cytogenetic technique used for assessment of radiosensitivity in human cells is cytokinesis-block micronucleus (CBMN) assay. The CBMN assay developed by Fenech and Morley in 1985 [13] is based on determination of the frequency of radiation induced micronucleus in peripheral blood lymphocytes. It also allows evaluating normal tissue morbidity in radiotherapy patients because of its reliability and easy performance, reproducibility and ease of automation using microscopy [14].

Objective of the study was to determine the feasibility of micronucleus and G2 chromosomal radiosensitivity assays for optimization of cancer treatment by comparing the specificity of chromatid breaks yield and micronuclei frequency in peripheral blood lymphocytes as biomarkers of individual radiosensitivity in radiotherapy patients.

\section{Materials and methods}

Selection of patients. This pilot study included three 57-66 years old male stage III prostate cancer patients without previous experience of exposure to ionizing radiation or genotoxic medicaments and assigned to receive postoperative pelvic radiotherapy. Treatment planning and radiation therapy contouring for selected individuals comprised of tumor bed after prostatectomy and pelvic lymphnodes as a target volume. Bladder, small bowel, rectum and femur heads were defined as organs at risk. Treatment plans were generated using 3D conformal external beam radiotherapy (3D-CRT) or volumetric modulated arc therapy (VMAT) techniques using 18-MV and 6-MV photon beams with a maximum variable dose rate of $600 \mathrm{MU} / \mathrm{min}$ respectively. The prescribed total dose of 66-68 Gy delivered in conventional fractionation ( 2 Gy/day) giving five fractions per week.
Blood sampling, cell culture and irradiation conditions. Peripheral blood samples were taken from each selected patients before starting radiotherapy, after receiving first fraction and after the completion of radiotherapy and collected into Li-heparin vacutainers. Lymphocytes cultures were set up by adding $0.5 \mathrm{ml}$ of heparinized whole blood to $4.5 \mathrm{ml}$ of F-10 medium supplemented with $13 \%$ fetal bovine serum, 2\% L-glutamine, and antibiotics (penicillin: $100 \mathrm{U} / \mathrm{ml}$, streptomycin: $100 \mu \mathrm{g} / \mathrm{ml}$ ). Cells proliferation was stimulated by exposing cultures to $2 \%$ phytohaemagglutinin (PHA). Cultures were incubated in a humidified air atmosphere at $37^{\circ} \mathrm{C}$ incubator in $5 \% \mathrm{CO}_{2}$ for 72 hours [15]. In vitro irradiation of lymphocytes aliquots with 1 Gy for G2 assay and 2 Gy for MN assay was carried out in T-105 X-ray therapy unit (Wolf Medizintechnik $\mathrm{GmbH}$, Germany) at room temperature $\left(23 \pm 2{ }^{\circ} \mathrm{C}\right)$ at a dose rate of $2.3 \mathrm{~Gy} / \mathrm{min}(70 \mathrm{keV}, 15 \mathrm{~mA})$.

G2 chromosomal radiosensitivity assay. All cell aliquots were exposed in vitro to 1 Gy $48 \mathrm{~h}$ after culture initiation. After irradiation one-half of culture was exposed to caffeine solution (4 mM), and another one remained caffeine-free. Division of irradiated cells in presence or without caffeine was initiated due to incubation of all cultures for $20 \mathrm{~min}$ at $37^{\circ} \mathrm{C}$ in a humidified incubator in $5 \% \mathrm{CO}_{2}$. Subsequent administration of colcemid to both cell cultures for $1 \mathrm{~h}$ allowed block of cell at metaphase. Lymphocytes were harvested and collected by centrifugation, treated in $75 \mathrm{mM}$ $\mathrm{KCl}$ solution for $15 \mathrm{~min}$ at $37^{\circ} \mathrm{C}$ and fixed in methanol: glacial acetic acid (3:1) and processed for analysis (spread on slides, dried and stained with $5 \%$ Giemsa)

Two distinct chromatid breaks yields were obtained for each patient: first conventional $\mathrm{G} 2$ yield without caffeine and the second comprised simulation of high AT radiosensitivity level based on caffeine-induced G2-M checkpoint arrest (G2 caf yield). At least 100 cells per person were scored (50 cell/ per yield). Chromatid breaks were analyzed in well-spread metaphases. Individual radiosensitivity (IRS) was calculated as a percentage of the high radiosensitivity level of AT patients using formula IRS $=(\mathrm{G} 2 / \mathrm{G} 2$ caffeine $) \times 100 \%$ [11]

Cytokinesis-block micronucleus (MN) assay. Blood samples collected before radiotherapy were divided over half: one part was in vitro irradiated with $2 \mathrm{~Gy}$, and another part was unexposed. Blood samples taken after first fraction and after radiotherapy did not undergo in vitro irradiation. Lymphocytes were cultured for $72 \mathrm{~h}$. Cytohalasin B (6 $\mu \mathrm{g}$ / $\mathrm{ml}$ ) was applied to block the cytokinesis of aliquots $24 \mathrm{~h}$ after culture initiation. Lymphocytes were collected by centrifugation, treated in cold $\left(4^{\circ} \mathrm{C}\right) 75 \mathrm{mM} \mathrm{KCl}$ solution and fixed once in methanol, glacial acetic acid, sodium chloride $(4: 1: 5)$ solution and next twice in methanol, glacial acetic 
acid (4:1). Subsequently cells were spread on slides, dried and stained with fluorescent stain DAPI (4', 6-diamidino2-phenylindole). At least 1000 binucleated cells were analyzed for each patient. The mean frequency of MN positive binucleated cell (BNC) (number of lymphocytes containing MN per 1000 binucleated cells) and the mean frequency of MN per 1000 binucleated cells (MN/1000) were calculated per sample [16].

Experimental procedure and data analysis. In order to evaluate possible radiotherapy-induced changes in IRS, frequency of $\mathrm{MN}$ positive $\mathrm{BNC}$ and $\mathrm{MN}$, investigation of radiation-induced chromosomal aberration employing $\mathrm{MN}$ and G2 assays were carried out simultaneously for each selected patient at each selected stage of treatment: before radiotherapy, after first 2 Gy fraction, and after receiving total radiotherapy dose. In $\mathrm{MN}$ assay background frequency of $\mathrm{MN}$ positive $\mathrm{BNC}$ and $\mathrm{MN}$ in non-irradiated cells were also evaluated.

Zeiss Axio Imager Z2 microscope equipped with the high-resolution camera and Metafer 4 software (Metasystems, Germany) supplemented by specific applications for images acquisition for G2 and MN assays (metaphase finder MSearch \& AutoCapt and Automated MN scoring module) facilitated scoring of chromosomal aberration.

Selected patients were under the supervision of radiation oncologist during the radiotherapy and follow-up every 3 to 6 months in the first year after completion of treatment. Acute normal tissue reactions including gastrointestinal (GI) and genitourinary (GU) side effects were observed and graded according to the Toxicity criteria of the Radiation Therapy Oncology Group (RTOG) and the European Organization for Research and Treatment of Cancer (EORTC) [17].

This study was implemented under the bioethical approval to conduct a biomedical research on evaluation of relationship between the occurrence of side effects using ionizing radiation therapy and chromosomal damage in lymphocytes No. L-14-07/1 issued by the Lithuanian Bioethics Committee.

\section{Results and discussion}

Results of MN and G2 assay of three prostate cancer patients at different stages of radiotherapy presented together with observed acute normal tissue side effects presented in table 1.

Cancer patients were evaluated according to their acute normal tissues side effects grades (RTOG/EORTC). One of selected patient experienced grade 2 genitourinary and grade 1 gastrointestinal side effects. The other two patients did not develop radiotherapy side effects (see Table 1).

Figure 1 presents the distribution of $\mathrm{MN}$ and $\mathrm{MN}$ positive BNC frequency in cancer patient by the treatment stage. The background frequency of MN in non-cancer individuals normally varies from 0 to 0.04 [15]. Cancer patients

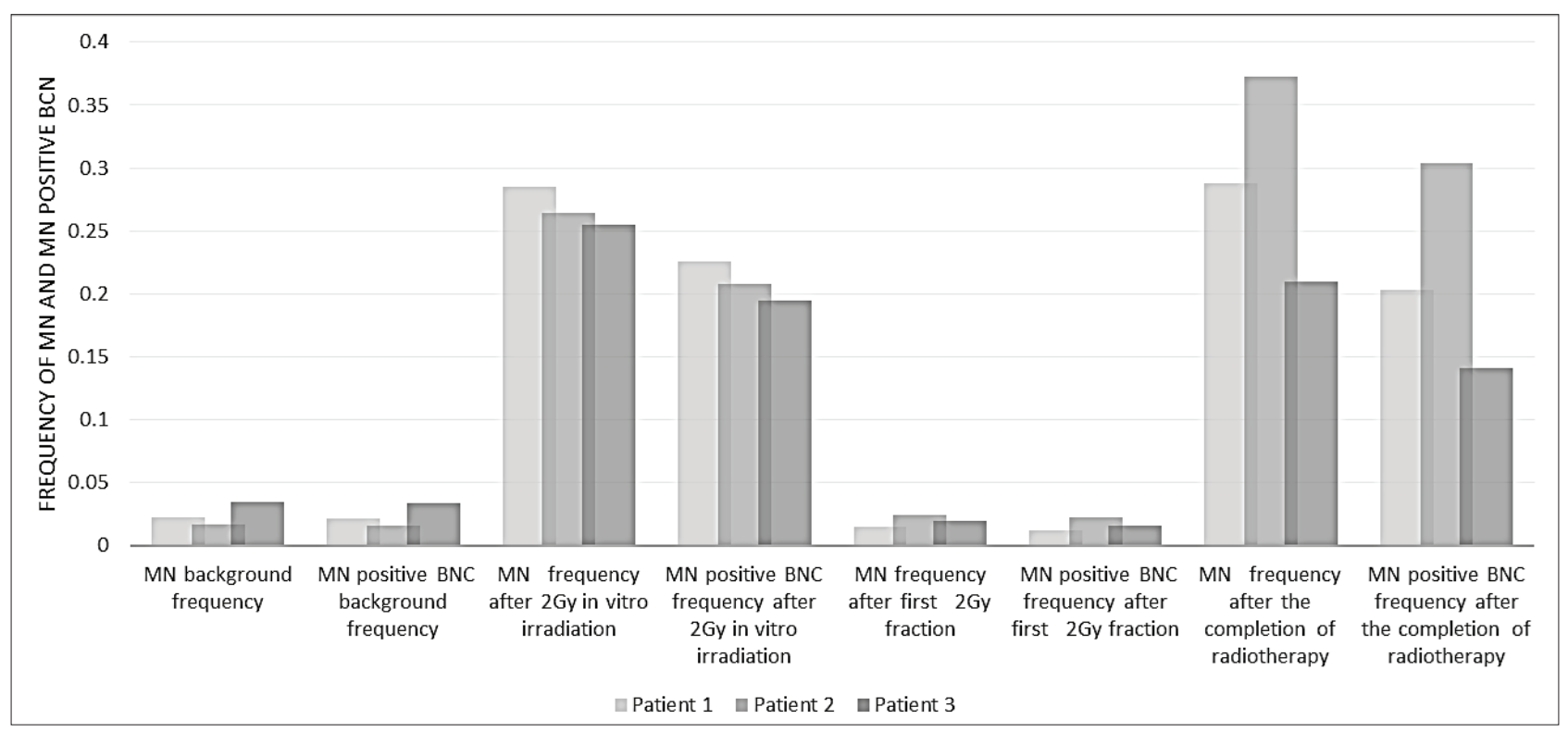

Figure 1. Distribution of $\mathrm{MN}$ and $\mathrm{MN}$ positive $\mathrm{BNC}$ frequencies in cancer patient in different stages of radiotherapy: $\mathrm{MN}$ - micronuclei, BNC - binucleated cell, MN frequency - number of micronuclei per 1000 binucleated cell, MN positive BNC- number of lymphocytes containing micronuclei per 1000 binucleated cells 
Table 1. Results of G2 and MN assays of three cancer patients at different stages of radiotherapy: before radiotherapy, after first 2 Gy fraction and after the completion of radiotherapy

\begin{tabular}{|c|c|c|c|c|}
\hline \multicolumn{2}{|c|}{ Patient No. } & 1 & 2 & 3 \\
\hline \multicolumn{2}{|c|}{ GU/GI toxicity grade } & $2 / 1$ & $0 / 0$ & $0 / 0$ \\
\hline \multirow{5}{*}{$\begin{array}{l}\text { Before } \\
\text { radiothe- } \\
\text { rapy }\end{array}$} & $\begin{array}{l}\text { MN background fre- } \\
\text { quency }\end{array}$ & 0.022 & 0.017 & 0.035 \\
\hline & $\begin{array}{l}\text { MN positive BNC fre- } \\
\text { quency }\end{array}$ & 0.021 & 0.016 & 0.034 \\
\hline & $\begin{array}{l}\text { MN frequency after } 2 \\
\text { Gy in vitro irradiation }\end{array}$ & 0.285 & 0.264 & 0.255 \\
\hline & $\begin{array}{l}\text { MN positive BNC fre- } \\
\text { quency after } 2 \text { Gy in } \\
\text { vitro irradiation }\end{array}$ & 0.226 & 0.208 & 0.195 \\
\hline & IRS & $53.2 \%$ & $52.3 \%$ & $46.4 \%$ \\
\hline \multirow{3}{*}{$\begin{array}{l}\text { After } \\
\text { the first } \\
\text { fraction } \\
\text { of radi- } \\
\text { otherapy }\end{array}$} & MN frequency & 0.015 & 0.024 & 0.02 \\
\hline & $\begin{array}{l}\text { MN positive BNC fre- } \\
\text { quency }\end{array}$ & 0.012 & 0.022 & 0.016 \\
\hline & IRS & $59.3 \%$ & $44.4 \%$ & $40.8 \%$ \\
\hline \multirow{3}{*}{$\begin{array}{l}\text { After the } \\
\text { comple- } \\
\text { tion of } \\
\text { radiothe- } \\
\text { rapy }\end{array}$} & MN frequency & 0.288 & 0.373 & 0.21 \\
\hline & $\begin{array}{l}\text { MN positive BNC fre- } \\
\text { quency }\end{array}$ & 0.203 & 0.304 & 0.141 \\
\hline & IRS & $63.9 \%$ & $44.8 \%$ & $43.5 \%$ \\
\hline
\end{tabular}

can be characterized by higher MN frequency [18], but spontaneous MN frequency of investigated samples (from 0.017 to 0.035 ) was in line with background level for healthy individuals. $\mathrm{MN}$ and $\mathrm{MN}$ positive $\mathrm{BNC}$ frequencies after 2 Gy in vitro irradiation in all patients increased from 7 to 16 times in comparison with background. Values of these parameters remain very similar to background after the first 2 Gy fraction of radiotherapy, but at the end of the treatment observed tendency in increase of $\mathrm{MN}$ and $\mathrm{MN}$ positive $\mathrm{BNC}$ frequencies was comparable to $2 \mathrm{~Gy}$ in-vitro evoked effect (see Figure1).

Highest $\mathrm{MN}$ and $\mathrm{MN}$ positive $\mathrm{BNC}$ frequencies $(0.285$ and 0.226 respectively) after 2 Gy in vitro irradiation in lymphocytes collected before radiotherapy were observed in patient No.1 that experienced grade 2 and 1 side effect. However, highest $\mathrm{MN}$ and $\mathrm{MN}$ positive $\mathrm{BNC}$ frequencies after the first 2 Gy fraction as well as completion of treatment were determined for patient No. 2 which has no adverse radiation effect. Thus, not clear tendency in changes of $\mathrm{MN}$ and $\mathrm{MN}$ positive $\mathrm{BNC}$ frequencies during radiotherapy could be observed. It could be explained by high inter and intra individual variables influencing $\mathrm{MN}$ index in lymphocytes [19]. Higher increase of MN frequency in comparison with increase of MN positive BNC number after irradiation was also observed. This results can indicate

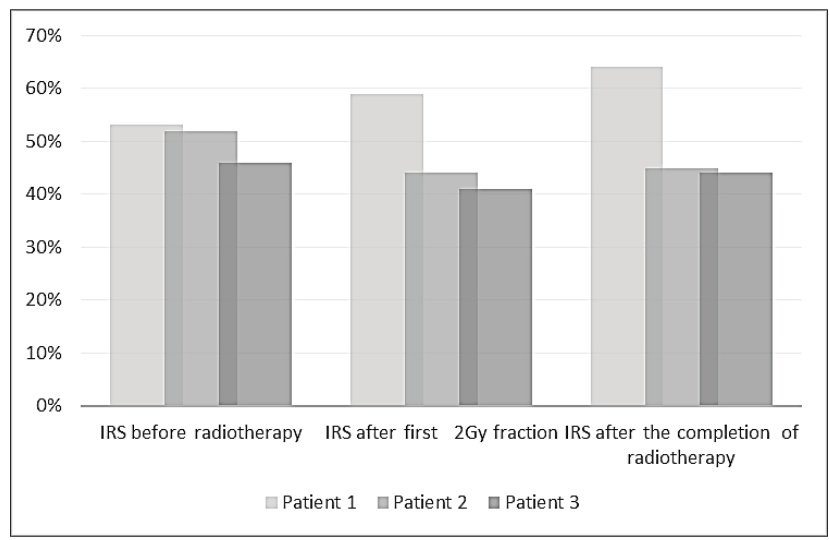

Figure 2. Distribution of IRS in cancer patient in different stages of radiotherapy: IRS - Individual radiosensitivity (IRS) calculated as a percentage of the high radiosensitivity level of AT patients using formula IRS $=(\mathrm{G} 2 / \mathrm{G} 2$ caffeine $) \times 100 \%$

that higher number of $\mathrm{MN}$ within one cell arise more likely than formation of new $\mathrm{MN}$ positive $\mathrm{BNC}$ due to irradiation of cancer patient.

Under the Pantelias et al. [11] proposed G2 assay protocol, individuals can be classified according to IRS cut-off value as radioresistant (IRS $<30 \%)$, normal $(30 \% \leq$ IRS $\leq$ $50 \%$ ) and radiosensitive (IRS $>50 \%$ ). It was also suggested to categorize individuals with IRS $>70 \%$ as highly radiosensitive. According to this, results of G2 assay allowed to classify patients No.1 and No. 2 as radiosensitive (IRS $=53.2 \%$ and $52.3 \%$ respectively) and patient No. 3 - as normal (IRS $=46.4 \%$ ). Highest IRS before radiotherapy was also determined for patient No. 1 who has experienced side effects, but difference between IRS of patient No. 1 and patient No. 2 was very small. Figure 2 represents distribution of IRS in cancer patient in different stages of radiotherapy.

However, unlike the results of MN assay, the IRS value of patient No. 1 remained highest comparing to two other individuals after first 2 Gy fraction as well as after the completion of radiotherapy (see Figure 2). Even more, the IRS of patient experienced adverse radiation reaction gradually raised from $53.2 \%$ determined before radiotherapy to $63.9 \%$ observed after the end of treatment, meanwhile IRS of two other patients that did not have side effects vice versa decreased with following stage of radiotherapy. Because of this observation patient No. 1 remain classified as a radiosensitive after the completion of radiotherapy and as it could be expected further experienced side effect, since patient No. 2 felt to the category of normal (IRS decreased from $52.3 \%$ to $46.4 \%$ ) after the end of radiation treatment and did not have adverse radiation reactions. This radiotherapy-induced modification of IRS can be associated with 
attribute of pre-exposure to ionizing radiation to initiate an adaptive response leading to higher resistance of the organism to further irradiation (like tendency observed in case with patient No. 2) [20].

\section{Conclusions}

Pilot method-comparison study results indicate that both higher frequency of micronuclei and chromatid breaks yield size after in vitro irradiation in peripheral blood lymphocytes of cancer patients collected before radiotherapy correlate with development of higher degree of normal tissue reactions. Chromatid breaks appeared to be more sensitive than micronuclei frequency for assessment of irradiation-induced alterations in radiosensitivity during the radiotherapy that could affect development of radiotherapy side effects. Therefore, further investigations of more radiotherapy patients as well as healthy donors employing both G2 and MN assays are required to select the most sensitive method and reveal the possible correlation between individual radiosensitivity and adverse effect of radiotherapy.

\section{Acknowledgments}

Current study conducted in the framework of the International Atomic Energy Agency (IAEA) Coordinated Research Project "Strengthening of 'Biological dosimetry' in IAEA Member States: Improvement of current techniques and intensification of collaboration and networking among the different institutes" [CRP: E3.50.08] under the research project "Possibility for optimization of patient doses in radiotherapy due to identification of radiation sensitive patients using cytogenetic methods" which is part of. In vitro irradiation carried out in National Cancer Institute.

\section{References}

1. Kron T. Reduction of margins in external beam radiotherapy. JMed Phys 2008; 33(2):41-42.

http://dx.doi.org/10.4103/0971-6203.41190

2. Gamulin M, Kopjar N, GrgiM, Rami S, Viculin T, Petkovi, Garaj-Vrhovac V. Cytogenetic follow-up in testicular seminoma patients exposed to adjuvant radiotherapy. Collegium antropologicum 2010; 34(2):455-465.

3. Auer J, Keller U, Schmidt M, Ott O, Fietkau R, Distel LV. Individual radiosensitivity in a breast cancer collective is changed with the patients' age. Radiol and Oncol 2014; 48(1):80-86. http://dx.doi.org/10.2478/raon-2013-0061

4. Di Giorgio M, Sardi M, Busto E, Vallerga M, Taja M, Mairal L. Assessment of individual radiosensitivity in human lymphocytes using micronucleus and microgel electrophoresis "Comet" assays. 11th International Congress on the International Radiation Protection Assosiation; Madrid, Spain 2004; 53-60.
5. Greve B, Bölling T, Amler S, Rössler U, Gomolka M, Mayer C,Popanda O, Dreffke K, Rickinger A, Fritz E, Eckardt-Schupp F, Sauerland C, Braselmann H, Sauter W, Illig T, Riesenbeck D, Könemann S, Willich N, Mörtl S, Eich HT, Schmezer P. Evaluation of different biomarkers to predict individual radiosensitivity in an inter-laboratory comparison-lessons for future studies. PLoS One 2012; 7(10): e47185.

http://dx.doi.org/10.1371/journal.pone.0047185

6. Popanda O, Ebbeler R, Twardella D, Helmbold I, Gotzes F, Schmezer P,Thielmann HW, von Fournier D, Haase W, Sautter-Bihl ML, Wenz F, Bartsch H, Chang-Claude J. Radiationinduced DNA damage and repair in lymphocytes from breast cancer patients and their correlation with acute skin reactions to radiotherapy. Int J Radiation Oncology Biol Phys 2003; 55 (5): $1216-1225$.

http://dx.doi.org/10.1016/S0360-3016(02)04415-2

7. Huber R, Braselmann H, Geinitz H, Jaehnert I, Baumgartner A, Thamm R, Figel M, Molls M, Zitzelsberger H. Chromosomal radiosensitivity and acute radiation side effects after radiotherapy in tumor patients - a follow-up study. Radiat Oncol 2011; 6:32.

http://dx.doi.org/10.1186/1748-717X-6-32

8. Herd O, Francies F, Kotzen J, Smith T, Nxumalo Z, Muller X, Slabbert J, Vral A, Baeyens A. Chromosomal radiosensitivity of human immunodeficiency virus positive/negative cervical cancer patients in South Africa. Mol Med Rep2016; 13(1):130-136.

9. Mozdarani H, Mansouri Z, Haeri SA. Cytogenetic Radiosensitivity of G0 - Lymphocytes of breast and esophageal cancer patients as determined by micronucleus assay. J Radiat Res 2005; (46):111-116.

http://dx.doi.org/10.1269/jrr.46.111

10. Pinn ME, Gold DG, Petersen IA, Osborn TG, Brown PD, Miller RC. Systemic lupus erythematosus, radiotherapy, and the risk of acute and chronic toxicity: the Mayo Clinic Experience. Int J Radiat Oncol Biol Phys 2008; 71(2):498-506.

http://dx.doi.org/10.1016/j.jijrobp.2007.10.014

11. Pantelias GE, Terzoudi GI. A standardized G2-assay for the prediction of individual radiosensitivity. Radiother Oncol 2011; 101(1):28-34.

http://dx.doi.org/10.1016/j.radonc.2011.09.021

12. De Ruyck K, de Gelder V, van Eijkeren M, Boterberg T, de Neve W, Vral A, Thierens H. Chromosomal radiosensitivity in head and neck cancer patients: evidence for genetic predisposition?Br J Cancer 2008; 98(10):1723-1738.

http://dx.doi.org/10.1038/sj.bjc.6604345

13. Fenech M, Morley AA. Measurement of micronuclei in lymphocytes. Mutat Res 1985; 147(1-2):29-36. http://dx.doi.org/10.1016/0165-1161(85)90015-9

14. Selvan GT, Bhavani M, Vijayalakshmi J, Solomon FDP, Chaudhury NK, Venkatachalam P. Delayed mitogenic stimulation decreases DNA damage assessed by micronucleus assay in human peripheral blood lymphocytes after (60)Co irradiation. 
Dose Response 2014; 12(3):498-508.

http://dx.doi.org/10.2203/dose-response.13-060.Selvan

15. IAEA. Cytogenetic Dosimetry: applications in preparedness for and response to radiation emergencies. IAEA EPR-Biodosimetry Series. International Atomic Energy Agency, Vienna, 2011.

16. Fenech M. Cytokinesis-block micronucleus cytome assay. Nature Protocols 2007; 2(5):1084-1104. http://dx.doi.org/10.1038/nprot.2007.77

17. Cox JD, Stetz J, Pajak TF. Toxicity criteria of the Radiation Therapy Oncology Group (RTOG) and the European Organization for Research and Treatment of Cancer (EORTC). Int J Radiat Oncol Biol Phys 1995;30; 31(5):1341-6.

18. Ramyar A, Aghamohammadi A, Mozdarani H, Mahmoodi M, Azimi C, Safari Z, Nedaei HA, Farzanfar F, Rezaei N, AsadiShekaari M, Esfahani M, Hosseini SK, Yazdani M, Abolhassani H, Khalesi F, Mohagheghi MA. Assessment of in vitro chromosomal sensitivity to low doses of gamma irradiation in patients with acute lymphoblastic leukemia. BCCR 2011; 2:2-6.

19. Fenech M. Important variables that influence base-line micronucleus frequency in cytokinesis-blocked lymphocytes - a biomarker for DNA damage in human populations. Mutat Res 1998; 404:155-165. http://dx.doi.org/10.1016/S0027-5107(98)00109-2

20. Pollycove M, Feinendegen LE. Biologic responses to low doses of ionizing radiation: detriment versus hormesis part 2. Dose responses of organisms. J Nucl Med 2001; 42(9):26-32.

\section{GALIMYBIŲ TAIKYTI CHROMOSOMŲ RADIOJAUTRUMO NUSTATYMĄ MIKROBRANDUOLIŲ IR G2 METODAIS, SIEKIANT OPTIMIZUOTI SPINDULINI GYDYMĄ, PALYGINIMAS}

K. Guogytė, A. Plieskienè, O. Sevriukova, R. Ladygienė, J. Žiliukas, V. Janušonis

Raktažodžiai: individualus radiojautrumas, chromosomų radiojautrumo G2 stadijoje analizè, sustabdytos citokinezès mikrobranduolių analizè, spindulinis gydymas.
Santrauka

Jonizuojančioji spinduliuotė yra plačiai naudojama piktybiniams navikams gydyti. Priklausomai nuo žmogaus radiojautrumo, jonizuojančioji spinduliuotė gali sukelti skirtingus organizmo atsakus. Todèl individualaus radiojautrumo vertinimas galètų būti naudojamas kaip pagalbinè priemonè optimizuojant spindulini gydimą. Sustabdytos citokinezès mikrobranduolių ir chromatidžių trūkių G2 ląstelès ciklo fazèje tyrimai periferinio kraujo limfocituose yra vieni tinkamiausių metodų individualiam radiojautrumui nustatyti. Mūsų darbo tikslas buvo atlikti bandomajị vėžiu sergančių pacientų, kuriems skiriamas spindulinis gydymas, radiojautrumo nustatymą minètais dviem metodais siekiant palyginti chromosomų trūkių ir mikrobranduolių susidarymo dažnių periferinio kraujo limfocituose, kaip potencialių radiojautrumo biologinių žymenų specifiškumą. Tyrimo metu buvo pastebèta teigiama koreliacija tiek tarp mikrobranduolių, tiek ir tarp chromatidžių trūkių susidarymo dažnio po tirtų pacientų periferinio kraujo limfocitų in vitro apšvitos jonizuojančiaja spinduliuote ir spindulinio gydymo sukeltų šalutinių efektų pasireiškimo. Tačiau, vertinant individualaus radiojautrumo pokyčius spindulinio gydymo eigoje, kurie taip pat gali turèti įtakos spindulinėms reakcijoms pasireikšti, G2 metodas pasirodè esantis jautresnis nei mikrobranduolių analizè. Atsižvelgiant ị gautus rezultatus būtina tęsti tyrimus ištiriant daugiau vẻžiu sergančių pacientų, taip pat ir sveikų donorų, siekiant parinkti jautriausią metodą individualiam radiojautrumui nustatyti ir galimam ryšiui tarp individualaus radiojautrumo ir šalutinių spindulinio gydymo sukeltų reakcijų atskleisti.

Adresas susirašinèti: olga.sevriukova@rsc.lt

Gauta 2016-11-03 